\title{
EFL Teachers' Self-Efficacy Beliefs, Pedagogical Success and Students' English Achievement: A Study on Public Preparatory Schools in Bahir Dar Town, Ethiopia
}

\author{
Girma Wossenie
}

Department of English Language and Literature, Bahir Dar University, Post Box No: 79, Bahir Dar, Ethiopia

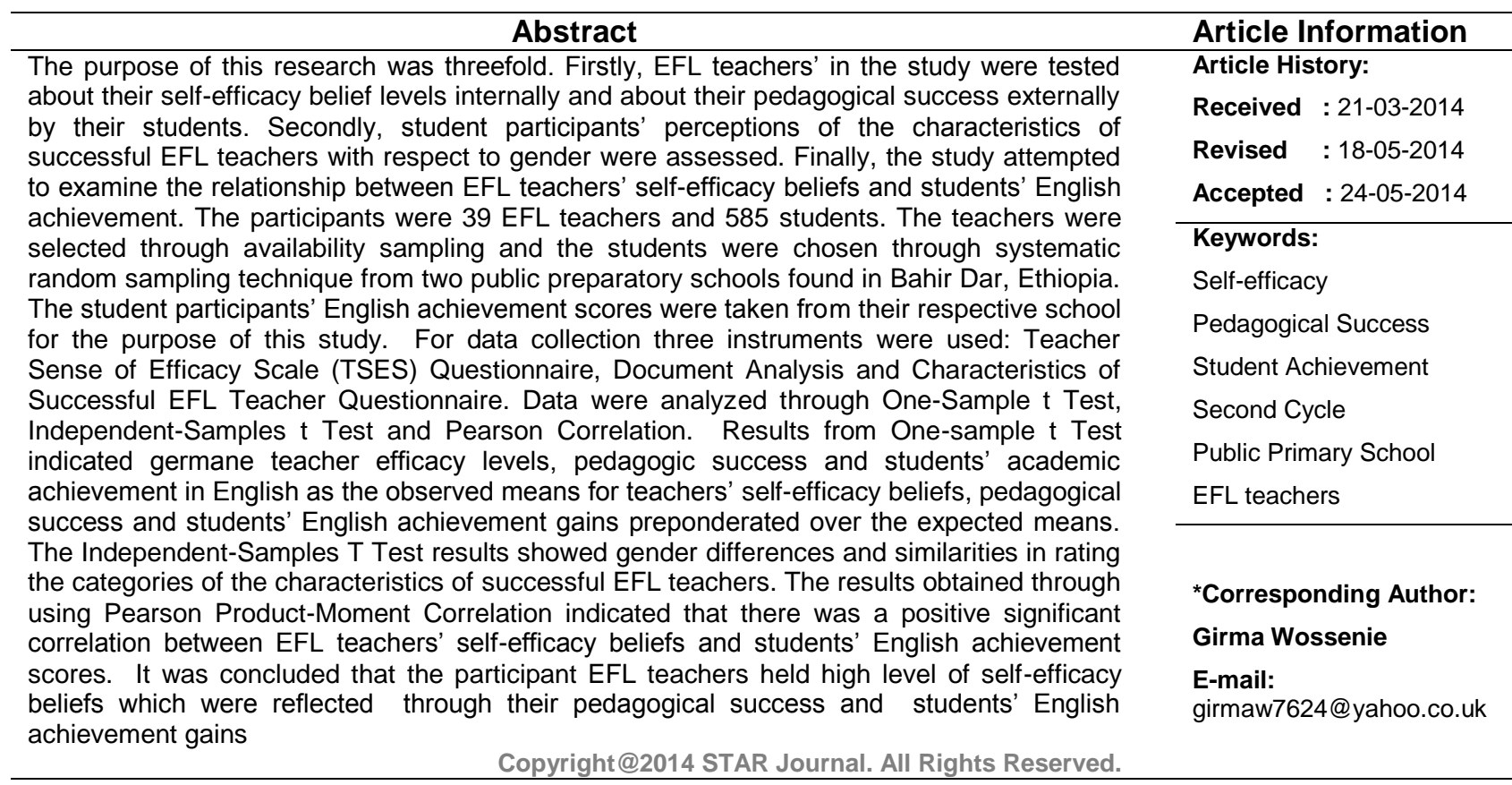

\section{INTRODUCTION}

Conducting a study on teachers' self-efficacy beliefs, pedagogical success and students' achievement in different settings is educative because EFL teaching practices and conditions show considerable variation within and across countries, and variations in teaching environments and teaching practices may influence teachers' beliefs about their roles and responsibilities (Ho and $\mathrm{Hau}, 2004)$. For example, teachers in East Asian settings may have very different day-to-day working experiences than teachers in North American settings due to differences in teacher preparation, induction, professional development, and expectations for student behavior and achievement (Preus, 2007; Yeom and Ginsburg, 2007). Teachers in European settings like Cyprus may work under a more highly centralized education system than most North American teachers, and may be motivated to enter teaching for reasons different than American teachers (Zembylas and Papanastasiou, 2004). This implies that the concept of teachers' self-efficacy may or may not be congruent with self-efficacy theory and research into it at various contexts is of key importune to see if teacher are equipped with germane self-efficacy levels in EFL classroom teaching and learning.

Self-efficacy beliefs according to Bandura's (1986) social cognitive theory refer to individuals' beliefs about their capabilities to successfully carry out a particular course of action. Considerable research supports the claim that self-efficacy is an important influence on human achievement in a wide variety of settings, including education, health, sports, and work (Bandura, 1997). In educational contexts, research has shown that students' self-efficacy plays an important role in influencing achievement and behavior, but there is increasing evidence that teachers' sense of self-efficacy also plays a key role in influencing important academic outcomes.

Teachers' self-efficacy is related to higher levels of student achievement and student motivation, and has been shown to influence teachers' instructional practices, enthusiasm, commitment, and teaching behavior 
(Skaalvik and Skaalvik, 2007; Tschannen-Moran and Woolfolk Hoy, 2001; Wolters and Daugherty, 2007).

Teachers with low levels of self-efficacy experience more difficulties with student misbehavior, are pessimistic about student learning, and experience higher levels of job-related stress and lower levels of job satisfaction (Bandura, 1997; Caprara, Barbaranelli, Borgogni, and Steca, 2003; Caprara, Arbaranelli, Steca, and Malone, 2006; Lee, Dedrick, and Smith, 1991). The relationship between TSE and job satisfaction is especially important because job satisfaction has been shown to be significantly related to job performance across a wide range of work settings (Judge, Thoresen, Bono, and Patton, 2001), and more importantly, is considered a critical element affecting teachers' attitudes and efforts in their daily work with children (Caprara et al., 2003). Exploring TSE may have implications for teachers' teaching performance, and by extension, the academic achievement of students.

Although TSE may be a universally valid factor underlying teaching and learning, there has been no local research exploring how TSE operates in relation to EFL teachers' classroom teaching performance- pedagogical success. In other words, to the knowledge of the present researcher a scant attention is paid as to how self-efficacy and pedagogical success operates in our EFL classroom teaching and learning contexts, and this provides adequate reason to conduct a similar research on the topic under investigation.

In Ethiopia, EFL teachers at all levels of teaching face formidable challenges resulting from heavy teaching workloads, shifting educational polices and expectations, deluge of directives from educational officials, and changes and developments in education and in society at large putting the teacher in a state of difficulty. Moreover, at present we know that the profusion of new knowledge in communication technologies have brought new possibilities to the education sector in general and to ELT in particular, but at the same time they have placed more demands on teachers. All of these are weighing EFL teachers down and possibly putting a negative complexion on their classroom teaching and learning.

In order to minimize a complex combination of difficulties that EFL teachers face in today's classrooms, one may think of a diminutive concept with a very big impact - teachers' self-efficacy beliefs. The beliefs teachers hold about their capabilities to face these challenges play a strong role in influencing student learning and teachers' job commitment (TschannenMoran and Woolfolk Hoy, 2001). In recent years, teachers' self efficacy (TSE)-beliefs teachers hold that they can positively influence student learning-has been shown to demonstrate a profound influence on the daily lives of teachers and their students.

In addition to this, defining effective EFL classroom teaching by students can be used as a springboard for EFL teachers to explore the nature of their own classroom decision-making and practices and to develop strategies for critical self- reflection and change. Considering the uniqueness of English language teaching in terms of subject matter knowledge, pedagogical knowledge, and socio/affective skills, the characteristics of effective foreign language teachers need to be investigated in- depth rather than simply applying what was found in general education to English as a foreign language teaching.

Although considerable oversea research has shown that TSE has a strong influence on teaching and learning process and on student academic achievement, there are no local studies investigating the relationship between teachers' self-efficacy beliefs and pedagogical success in EFL classroom teaching and learning. Given the fact that every teaching-learning situation is unique, and that subjects differ from one another, there are teaching principles and behaviors that are deemed to be effective in one context, but less effective in another teaching contexts (Brosh, 1996).

The present researcher attempted to investigate EFL teachers' self-efficacy beliefs as one of the factors to bring about the desirable qualities or characteristics of successful EFL teachers and students achievement in English. Thus, the following research questions were formulated.

1. What self-efficacy beliefs do EFL teachers hold?

2. What are the distinctive characteristics of successful EFL teachers perceived by the students?

3. Are the characteristics of successful EFL teachers perceived by the male students different from those perceived by the female students?

4. Is there any systematic relationship between EFL teachers' self-efficacy beliefs and students' English language achievements?

In the ensuing paragraphs teachers' self-efficacy beliefs and the characteristics of successful teacher are discussed to underpin the research question posed above.

Efficacy is the belief in one's ability to carry out the necessary actions to achieve a certain desired outcome (Bandura, 1997). This means that one's sense of efficacy affects personal feelings, thoughts and motivations. People with higher efficacy possess a high quality of decision making. On the other hand, people with low efficacy give up quickly, have low aspirations for achievement, and experience anxiety, which causes stress and burnout (Gibson and Dembo, 1984).

In educational contexts, where teachers have to meet teaching demands, teacher efficacy could be an important personal resource in coping with job stress. As a result, teacher self-efficacy is 'the teacher's belief in his or her capability to organize and execute courses of action required to successfully accomplishing a specific teaching task in a particular context' (Tschannen-Moran, WoolfolkHoy and Hoy, 1998, p, 233).

Studies on teacher efficacy have provided evidence of the significance of the role of efficacy on teachers' behavior. Findings indicate that teachers" efficacy beliefs not only have considerable influence on their instructional practices and classroom behavior but also have formative effects on their students' achievement and motivation(Goddard, Hoy and Woolfolk-Hoy, 2004; Tschannen-Moran and Barr's, 2004 ; Ashton and Webb, 1986). In this regard, teachers with high efficacy beliefs manage negative affective experiences better than teachers with low efficacy beliefs who may succumb to 
anxiety. Moreover, highly efficacious teachers are more sensitive to the needs of students, are more enthusiastic in their teaching (Allinder1994), and are more willing to work efficiently with students, who have behavior problems (Hoy and Woolfolk, 1990).

Ross (1994, p. 345) analyzed 88 teachers' efficacy levels and concluded that highly efficacious teachers are willing to:

1) Learn and use new approaches and strategies for teaching, (2) use management techniques that enhance student autonomy and diminish student control, (3) provide special assistance to low achieving students, (4) build students' self perceptions of their academic skills, (5) set attainable goals, and (6) persist in the face of student failure.

A number of studies, conducted in L1 context, have demonstrated the relationship between teachers' selfefficacy and their instructional behaviors. Gibson and Demo (1984), for example, indicated a high correlation between teachers' sense of efficacy and their persistence in the presentation of lessons, feedback presentation, and support scaffolding for weaker students. In a similar study, Pajares (1992) found a strong relationship between teachers' educational beliefs and their planning, instructional decisions, classroom practices, and subsequent teaching behaviors. He concluded that "beliefs are far more influential than knowledge in determining how individuals organize and define tasks and problems and are stronger predictors of behavior" (Pajares, 1992, p 311 ). On the other hand, teachers with a low level of efficacy have been found to be cynical not only of their own abilities, but also of the abilities of their students and colleagues (Siebert, 2006). They also tend to undermine students' cognitive development as well as students' judgments of their own capabilities (Pajares and Schunk, 2001, as cited in Siebert, 2006).

Previous studies have also pointed to the role of teacher sense of efficacy in shaping students' attitudes toward school and subject matter, i.e., the higher the teaching efficacy of a teacher, the greater the students' interest in school and learning materials. Beyond shaping students' attitudes, teacher efficacy has been also associated with the degree of personal commitment (Coladarci, 1992, cited in Tschannen-Moran et al., 1998, p. 9) and enthusiasm in teaching (Allinder, 1994) exhibited by the teacher.

In short, theoretical and empirical views in the literature indicate that self-efficacy beliefs influence several factors, one of which is the individual teacher's classroom teaching performance (Bandura, 1986). As a result, it seems cogent to envisage the likelihood of a relationship between EFL teachers' self-efficacy beliefs and pedagogical success.

A plethora of research conducted in order to identify the characteristics of effective teachers that influence students' learning and achievement (Brosh, 1996; Koutsoulis, 2003; Lang et al., 1993; Lowman, 1995; Park and Lee, 2006; Witcher et al., 2001). These studies asked students to identify effective teacher characteristics by means of self-report questionnaires or interviews. For example, Lang et al. (1993) developed a list of 32 characteristics of effective teachers through interviews with college teachers, and asked 167 participants (administrators, chairpersons, college teachers, and students) to identify and rank three characteristics considered important to teaching. They found that the teachers rated 16 characteristics significantly different from the students and that the overall difference was significant. The mean ratings for three characteristics including knowledgeable of world events and knowing students and teaching them in ways which they learn best were higher for student respondents, whereas the remaining 13 characteristics including knowing the subject well and encouraging students to learn independently received higher mean ratings from teacher respondents.

There is a growing body of theoretical and empirical evidence that if teachers are to be responsive to student needs and improve the effectiveness of student achievement, they must first discern what students define as effective teaching. Horwitz (1987) contended not to underestimate student beliefs about language learning: "When language classes fail to meet student expectations, students can lose confidence in the instructional approach and their ultimate achievement can be limited" (p. 119). The rationale behind knowing students' perception and attitudes about the characteristics of successful EFL teachers is not to appease or indulge the weakness of the students but ideas and concepts elicited from them can be used as source of information for teachers' reflection and selfevaluation which in turn help teacher develop professionally. Despite the importance of knowledge about student perceptions as an important informant to effective EFL classroom teaching, there is a lack of studies in the field of English language teaching, especially in Ethiopian context.

The desirable characteristics of foreign language teachers consist of several underlying constructs including subject matter knowledge, pedagogical knowledge, and socio/affective skills (Park and Lee, 2006). Some characteristics of effective teachers are universal and pertinent to general education while others are domain-specific. For example, according to Faranda and Clarke (2004) the characteristics of effective English teacher are divided into five major categories: Rapport, Delivery, Fairness, Knowledge and Credibility, and Organization and Preparation. Study by Brosh (1996) envisaged language teaching effectiveness from the viewpoint of communication and classified the characteristics of effective language teachers as follows: teacher-student interaction styles, teaching methods, planning and organization, interest and attention in the class, importance of personality in the classroom. Although there are a number of different classifications regarding the characteristics of successful English language teacher, the present researcher opted for using the one developed by Moafian and Pishghadam (2009) for its comprehensiveness to capture the desired qualities of successful EFL teachers.

Therefore, this study aimed at identifying EFL teachers' sense of self-efficacy beliefs in their pedagogical success and students' English achievement gains. The dearth of local research into EFL teachers' self-efficacy beliefs in their success and 


\section{Girma Wossenie}

students' academic achievements scores in ELT may show a clear need to undertake this kind of research. The present study also assessed the relationship between EFL teachers' self-efficacy beliefs in their pedagogical success and students' academic achievements gains in English due to the fact that there is a plethora of new oversea research findings' illustrating the importance of the two constructs in target language teaching and learning, albeit difficult to find this sort of research in Ethiopian EFL settings.

Investigating EFL teachers' self-efficacy beliefs in their pedagogical success and students' academic achievement is beneficial to teachers and students as well as for ELT researchers. For the EFL teachers, they can check the appropriateness of their beliefs regarding English language teaching and learning based on insight gained from current research findings. Moreover, EFL teachers can discern what their students' expect from them and develop germane pedagogical knowledge and techniques through critical reflection and self-evaluation. To this end, the present research looked into the two constructs separately and then attempted to see their relationships in a local EFL context.

\section{MATERIALS AND METHODS}

\section{Method of the Study}

From different types of studies in quantitative research methodologies, the researcher used the descriptive survey method to generate data for the current research.

\section{Research Participants and Sampling Procedures}

The participants of this study consisted of 39 English teachers and 585 students. The teachers and the students were taken from two public preparatory schools (Tana Higher Education Preparatory and Bahir Dar Higher Education Preparatory Schools found in Bahir Dar town, Ethiopia.

The Teachers' Self-efficacy Scale (TSES) was administered to 39 English teachers after receiving voluntary consent from the teachers and from the school administrators. The participants, having teaching experience ranging from 25 to 39 years with a mean of 29 years, were asked to rate themselves on a 5-point Likert scale of TSES which was developed by Tschannen- Moran and Woolfolk-Hoy (2001).

Since the sample size for EFL teachers was small and below one-hundred, the present researcher included all the 39 English teachers found in the two schools as participants in the study. The total sampling frame list for the students found in the two schools were 1,765 and for this research purpose 585 ( $M=335$; $\mathrm{F}=250$ ) students were chosen through systematic random sampling. Out of 585 (33.1\%) sampled students, male and female students constituted $57.2 \%$ and $42.7 \%$ respectively.

For the student participants in the two schools, 'Characteristics of successful EFL teachers' questionnaire developed by Moafian and Pishghadam (2009) was administered. The administration of the questionnaire was made by selected subject teachers other than English teachers as the questionnaire is all
Sci. Technol. Arts Res. J., April-June 2014, 3(2): 221-228

about the desirable qualities of English language teachers and their presence during student questionnaire filling may not create a convivial atmosphere and influence the rating of the students in this study. Concerning the participants' English language achievements, the current researcher collected the necessary information from the two schools' record offices with the permission of the school administrators.

Both the teacher and the student participants in this study were assured that their responses to the questionnaires would be kept confidential and used only for research purpose.

\section{Instruments}

Two instruments were used to generate the necessary data for the research. The first one was the 'Characteristics of successful EFL teachers' questionnaire which was developed by Moafian and Pishghadam (2009). The present researcher slightly adapted and employed this instrument to asses EFL teachers' teaching performance and success in language teaching. The questionnaire comprises 47 items ranging from 'Never' to 'Always' and measures the behavior indicated in each item. The results of prior reliability analysis showed that the total reliability of the questionnaire was found very high (Cronbach's alpha= 0.94). Moreover, the questionnaire measures the desired qualities of successful EFL teachers through 12 clusters of features or constructs: teaching accountability, interpersonal relationships, attention to all, examination, commitment, learning boosters, creating a sense of competence, teaching boosters, physical and emotional acceptance, empathy, class attendance, and dynamism (Moafian and Pishghadam (op.cit.). In this study, the total reliability estimate of the questionnaire, measured by using Cronbach's alpha and it was found 0.91 .

Another instrument to generate data for the study was the short version of Teachers' Sense of Selfefficacy Scale (TSES) developed by Tschannen- Moran and Woolfolk-Hoy (2001). The TSES was used because it encompasses the essential elements required to elicit the necessary data for the research in a succinct manner. It comprises 12 items including four items for each of the three subscales: Efficacy in student engagement; Efficacy in instructional strategies; Efficacy in classroom management. The items used to measure how much an individual EFL teacher can do concerning efficacy for engagement, efficacy for management, and efficacy for using instructional strategies. The TSES has been labeled "superior to previous measures of teacher efficacy in that it has a unified and stable factor structure" and because it is closely aligned with self-efficacy theory (Woolfolk Hoy and Burke Spero, 2005, p. 354). The reliability of the efficacy scale estimated through Cronbach's alpha coefficient and was found 0.87. Moreover, document analysis was made to get information regarding students' two semesters English language achievement gains from the two record offices of the schools. Descriptive and Inferential statistics were used to analyze and interpret the data by using the software package SPSS version 20. 
Girma Wossenie

\section{RESULTS}

To interpret the data collected and answer the research questions raised on EFL teachers' self-efficacy beliefs, pedagogical success and students' English achievements, the current researcher used both descriptive and inferential statistics. The results in Table 1 show observed mean differences across the three
Sci. Technol. Arts Res. J., April-June 2014, 3(2): 221-228

variables considered in this study. In Table 2, gender was deemed in relation to the sub-categories of EFL teachers' pedagogical success, and the results in Table 3 indicate the correlations between the variables. Accordingly, summary results of One-Sample T Test, Independent-Samples $\mathrm{T}$ Test and Correlation analysis are shown in Tables 1, 2 and 3 respectively.

Table 1: EFL Teachers' Self-efficacy Beliefs, Pedagogical Success and Students' English Achievements

\begin{tabular}{ccccccc}
\hline Constructs & N & $\begin{array}{c}\text { Expected } \\
\text { Mean }\end{array}$ & $\begin{array}{c}\text { Observed } \\
\text { Mean }\end{array}$ & $\begin{array}{c}\text { Std. } \\
\text { Deviation }\end{array}$ & df & $\begin{array}{c}\text { Sig. } \\
\text { (2-tailed) }\end{array}$ \\
\hline Efficacy & 12 & 36 & 49.08 & 4.638 & 38 & .000 \\
Success & 47 & 141 & 162.456 & 8.571 & 38 & .000 \\
Achievement & 585 & 50 & 69.75 & 11.671 & 584 & .000 \\
\hline
\end{tabular}

Table 2: EFL Teachers' Pedagogical Success with respect to Gender

\begin{tabular}{|c|c|c|c|c|c|c|c|}
\hline \multirow{3}{*}{ No } & \multirow{3}{*}{$\begin{array}{c}\text { Categories of Pedagogical } \\
\text { Success }\end{array}$} & \multicolumn{4}{|c|}{ Gender } & \multirow{3}{*}{ Df } & \multirow{3}{*}{$\begin{array}{l}\text { Sig. } \\
\text { (2-tailed) }\end{array}$} \\
\hline & & \multicolumn{2}{|c|}{ Male } & \multicolumn{2}{|c|}{ Female } & & \\
\hline & & Mean & $\begin{array}{c}\text { Std. } \\
\text { Deviation }\end{array}$ & Mean & $\begin{array}{c}\text { Std. } \\
\text { Deviation }\end{array}$ & & \\
\hline 1. & Accountability & 26.42 & 5.32 & 26.68 & 4.21 & 583 & 0.535 \\
\hline 2. & Interpersonal Relationships & 27.08 & 5.98 & 25.12 & 6.25 & 583 & 0.000 \\
\hline 3. & Attention to All & 20.94 & 3.30 & 18.86 & 3.95 & 583 & 0.000 \\
\hline 4. & Examination & 11.72 & 2.83 & 11.36 & 2.40 & 583 & 0.112 \\
\hline 5. & Commitment & 20.39 & 4.56 & 20.68 & 3.90 & 583 & 0.421 \\
\hline 6. & Learning Boosters & 14.01 & 3.75 & 14.34 & 3.18 & 583 & 0.260 \\
\hline 7. & Creating a sense of Competence & 14.01 & 3.75 & 14.34 & 3.18 & 583 & 0.260 \\
\hline 8. & Teaching Boosters & 7.88 & 2.10 & 7.08 & 1.80 & 583 & 0.000 \\
\hline 9. & Physical and Emotional Acceptance & 8.19 & 1.64 & 7.52 & 1.85 & 583 & 0.000 \\
\hline 10. & Empathy & 8.80 & 1.42 & 8.36 & 1.90 & 583 & 0.002 \\
\hline 11. & Class Attendance & 7.46 & 1.85 & 7.28 & 1.75 & 583 & 0.023 \\
\hline 12. & Dynamism & 7.46 & 1.85 & 7.28 & 1.75 & 583 & 0.234 \\
\hline
\end{tabular}

Table 3: Correlations between EFL Teachers' Efficacy Beliefs and Students' English Achievements

Efficacy $\frac{\text { Achievement }}{0.397^{\star}}$

*Indicates the existence of positive significant relationship at the level of 0.05

\section{DISCUSSION}

The present study examined the relations between EFL teachers' sense of self-efficacy in their pedagogical success and students' English achievement scores. In this section, the results derived from the data are discussed in the light of leading research questions, prior research findings and theoretical studies.

The results of a One -Sample $T$ Test for the three constructs are shown in Table 1 above. Based on the findings, teachers' efficacy beliefs in their pedagogical success and students' English language achievements showed significant differences as the observed means for efficacy, success and students' English achievement gains preponderated over the expected means, illustrating high EFL teachers' efficacy levels, pedagogical success and students' achievement gains in English language. In the ensuing paragraphs, each research question was addressed.

Research Question 1: What self-efficacy beliefs do EFL teachers hold? Concerning research question 1, the teacher participants were found efficacious as the observed mean outweighed the expected mean as can be seen from Table 1 above. One possible way to construe the high efficacy levels felt by EFL teachers in the study is the participants' long years of English language teaching experiences that ranged from 25 to 39 years with a mean of 29 years. Another possibility to look into the nature of high self-efficacy levels felt by the EFL teachers may be due to the fact that efficacious teachers' teaching knowledge base is rich, integrated and highly organized so that they are able to use it to promote active leaning, critical thinking and solve problems. This implies that the teachers in this study 


\section{Girma Wossenie}

have practical awareness on the involvement of their students in EFL task performances, proper execution of classroom management and the use of a variety of instructional strategies which are the main components of teacher self-efficacy beliefs.

The findings of this study is consistent with prior researches in that teachers with strong self-efficacy show high levels of planning and organization, readily accept new ideas and are more likely to test new methods to better meet the needs of their students (Guskey, 1988; Stein and Wang, 1988). These teachers also show more enthusiasm for teaching (Allinder, 1994; Wolters and Daugherty, 2007), are more engaged with their job and most likely to have a positive influence on students achievement (Tschannen-Moran and Woolfolk Hoy, 2001; Ashton and Webb, 1986). The findings from this study confirm Siebert's (2006) and Woolfolk Hoy's (1990) findings that there are significant differences between experienced and novice teachers regarding self-efficacy beliefs. Furthermore, Baduran (1997) noted that mastery and vicarious experiences as the major sources of efficacy.

There is a plethora of research literature and findings showing that teacher's self-efficacy beliefs can exert a considerable amount of influence on students' academic achievements. Teachers with a strong sense of self-efficacy are more open to new ideas and they are more willing to experiment with new methods at the same time offering students new and different learning opportunities or experiences (Tschannen-Moran and Woolfolk Hoy, 2001). In a similar vein, teachers 'selfefficacy beliefs are strongly linked with higher levels of student achievement and influence teachers' instructional practices, enthusiasm , commitment, and teaching behaviors that address both students' cognitive and affective side of leaning (Skaalvik and Skaalvik, 2007; Tschannen-Moran and Woolfolk Hoy, 2001). In other words, teachers with high self-efficacy beliefs are more likely to outperform teachers with low self-efficacy teachers regarding the implementation of didactic innovations in the classroom and use of classroom management approaches and employment of adequate teaching methods that encourage students' autonomy and reduce custodial control (Guskey, 1988).

Research Question 2: What are the distinctive characteristics of successful teachers as perceived by the students? In relation to question number 2 , the findings indicated that the student participants in this study have perceived their EFL teachers effective as the expected mean trailed behind the observed mean. At this juncture it may be suggested that EFL teachers' effectiveness in their teaching resulted in students' English achievement gains in this study. These results are congruent with the findings of (Brosh, 1996; Park and Lee, 2006) who argued that effective teachers influence students' learning and achievement.

There is a growing body of research findings that effective EFL teachers are self-efficacious and that their students are the best source of information to notice the distinctive characteristics of their successful teaching in both inside and outside of classrooms. The overarching findings in Table 1 indicated that teacher' self-efficacy beliefs have played an important role in teacher effectiveness. This is more often related to positive
Sci. Technol. Arts Res. J., April-June 2014, 3(2): 221-228

teaching behavior and student academic results. The findings go along with Tschannen-Moran and Woolfolk Hoy, (1998) who contend that one of the most reliable characteristics of effective teachers is their strong sense of efficacy. In addition to this, Suwandee (1995) argued that students are the best source to provide ample and rich information concerning teaching performance and the quality of teaching. In a similarly argument , Braskamp, Brandenburg and Ory (1984) explained that students are more appropriate sources when they are judging the following areas: the teacher's professional and ethical behavior; student-teacher relationship; workload; what they learned in the lessons or courses; fairness of grading; and teacher's ability to communicate clearly.

In this study attempt was made to see teaching performance in a two-pronged approach: EFL teachers' internal and external appraisal of their teaching performance. The internal aspect of teaching performance evaluation was made by the teachers themselves (i.e. through self-efficacy beliefs questionnaire) and the external evaluation was carried out by their students (i.e. through EFL teachers' pedagogical success questionnaire). The findings demonstrated that EFL teachers' self-efficacy beliefs and their teaching performance are aligned with the students' perceptions about their EFL teachers' performance which in turn helped discern desirable degree of students' English language achievement gains as illustrated in Table 1 . This seems to imply that student academic achievement scores are more likely to inform and reflect teacher's teaching performance and that learning outcomes are integral part of teaching.

Research Question 3: Are the characteristics of successful EFL teachers perceived by the male students different from those perceived by the female students? Regarding question number 3 , the findings in Table 2 above presented the way how the twelve categories constituting the characteristics of effective EFL teachers perceived by male and female students in the study. To identify gender preferences over the categories, twelve Independent-Samples T-Tests were computed. Important findings emerged from this study were the preferences showed by the male and female students over the desirable characteristics of their English language teachers. In other words, the findings highlighted the existence of a relatively colossal level of mean differences and similarities between male and female students preferences regarding the desirable qualities of EFL teachers that they would like to see in their EFL classrooms. For example, in category 1, $4,5,6,7,8$ and 10 moderate and in category 2,3 and 9 stark differences were noted concerning the qualities that male and female students wanted to observe in their EFL teachers' classroom teaching performance. However, in category $6,7,11$ and 12 male and female students showed that same preferences. Unfortunately, to the current researcher's information there are no prior research findings or literature to support this findings and further research may be conducted on the issue to draw a firm conclusion or to refute the present findings.

Research Question 4: Is there any systematic relationship between EFL teachers' self-efficacy beliefs and students' English language achievements? This question aimed to address the relationship between EFL 


\section{Girma Wossenie}

teachers' self-efficacy beliefs and students' English language achievement gains. Table 3 above indicates the existence of significant positive correlations $(r=0.397, P<0.05)$ between EFL teachers' self-efficacy beliefs and students' academic achievements in English. To arrive at such findings a Person ProductMoment Correlation Coefficient was run using SPSS version 20 so as to examine the magnitude of the relationship between teachers' efficacy in their pedagogical success and students' achievements gains in English as a foreign language teaching context where this study was conducted. This findings are in line with Bandura's(1997) idea that teachers' self-efficacy beliefs have strong relationship with teachers' motivation and performance together with their students' academic results. Similar findings were observed by Goddard, Hoy, and Woolfolk-Hoy (2004); Tschannen-Moran and Barr (2004) who noted salient relationship between efficacious teachers and students' academic achievement.

Furthermore, the findings in this research is consistent with Ross's (1994) conclusions that teachers who believe more in the effect of teaching on students' learning expect higher academic achievement gains of their students than those who believe less in this matter. The existence of positive relations between the constructs may indicate the need for giving constant attention for its sustainability in providing germane orientation and sensitization to EFL teachers at all levels of teaching about the interplay of efficacy, pedagogical success and students' achievement gains in English.

\section{CONCLUSIONS}

The findings from this study demonstrated that EFL teachers had high levels of self-efficacy experience which were reflected in their pedagogical success and students' English academic achievement scores.

Constant attention needs to be paid so as to strengthening EFL teachers' self-efficacy beliefs through targeting the sources of efficacy that enhance teacher professional development which in turn help to meet the growing demands of students' effective target language learning. This may lead us to pushback our understanding of teacher self-efficacy beliefs as a diminutive concept with big impact (Tschannen-Moran and Woolfolk Hoy, 2001) on teaching and student learning in EFL settings. Moreover, school administrators, along with different authorities in education, can play prominent roles in creating efficacious teachers by providing clear opportunities for successful experiences, positive modeling from successful peers, reflective teaching and verbal encouragement since teachers' efficacy beliefs have an overarching effect on the overall teaching learning contexts in general and on EFL teaching , pedagogical success and students' English language achievement gains in particular.

The findings of this research have some implications for English language teachers educators and authorities working with EFL teacher professional development projects so that they can make both on-job EFL teachers at various levels, and those engaged in EFL teacher preparation programs familiar with the idea of efficacy and the way how it influences teachers' pedagogical success and students' academic
Sci. Technol. Arts Res. J., April-June 2014, 3(2): 221-228

achievements in English. The underlying tenet here is that improving teachers' self-efficacy could improve students' academic achievements and this go along with Tschannen-Moran and Barr's (2004) idea that fostering teachers' self-efficacy beliefs increases students' performance.

The caveat in this study is that further research using TSES in pre-and in-service English language teacher preparation programs and in a variety of English as a foreign language teaching settings using multiple data gathering instruments may be a matter importance to examine the role of EFL teachers' self-efficacy beliefs, pedagogical success and students' English achievements in a wider perspective.

\section{REFERENCES}

Allinder, R.M. (1994). The relationship between efficacy and the instructional practices of special education teachers and consultants. Teacher Education and Special Education 17: 86-95.

Ashton, P.T and Webb, R.B. (1986). Making a Difference: Teachers' Sense of Efficacy and Student Achievement. New York: Longman.

Bandura, A. (1986). Social foundations of thought and action: A social cognitive theory. Englewood Cliffs, NJ: Prentice Hall.

Bandura, A. (1997). Self-efficacy: The exercise of control. New York: Freeman.

Brosh, H. (1996). Perceived characteristics of an effective language teacher. Foreign Language Annals 29(2): 2538.

Caprara, G. V., Barbaranelli, C., Borgogni, L., and Steca, P. (2003). Efficacy beliefs as determinants of teachers' job satisfaction. Journal of Educational Psychology 95: 821832.

Caprara, G. B., Barbaranelli, C., Steca, P., and Malone, P. S. (2006). Teachers' self efficacy beliefs as determinants of job satisfaction and students' academic achievement: A study at the school level. Journal of School Psychology 44: 473-490.

Gibson, S. and M. Dembo. (1984). Teacher efficacy: A construct validation. Journal of Educational Psychology 76: 569-582.

Goddard, R.D., Hoy, W.K. and Woolfolk-Hoy, A. (2004). Collective efficacy beliefs: Theoretical developments, empirical evidence, and future directions. Educational Research 33(3):3-12.

Guskey, T. (1988). Teacher Efficacy, Self-Concept and Student Leaning: The relationship of Collective Attitudes toward the Implementation of Instructional Innovation. Teaching and Teacher Education 4: 63-69.

Ho, I.T., and Hau, K.T. (2004). Australian and Chinese teacher efficacy: Similarities and differences in personal instruction, discipline, guidance efficacy and beliefs in external determinants. Teaching and Teacher Education 20: 313-323.

Horwitz, E.K. (1987). Surveying student beliefs about language learning. In: A. Wenden and J. Rubin (eds.), Learner strategies in language learning, pp. 119-129. Edgerwood Cliffs, N.Y.: Prentice-Hall.

Judge, T.A., Thoresen, C.J., Bono, J.E., and Patton, G.K. (2001). The job satisfaction-job performance 


\section{Girma Wossenie}

relationship: A qualitative and quantitative review. Psychological Bulletin 127: 376-407.

Koutsoulis, M. (2003). The characteristics of the effective teacher in Cyprus public high school: The students' perspective. Arlington, VA: American Association of School Administrators. (ERIC Eric Document Reproduction Service No. 478 761).

Lang, H., McKee, B. and Conner, K. (1993). Characteristics of effective teachers: A descriptive study of the perceptions of faculty and deaf college students. American Annals of the Deaf 138: 252-259.

Lee, V.E., Dedrick, R.F., and Smith, J.B. (1991). The effect of the social organization of schools on teachers' efficacy and satisfaction. Sociology of Education 64: 190-208.

Lowman, J. (1996). Characteristics of exemplary teachers. New Directions for Teaching and Learning 65: 33-40.

Moafian, F. and Pishghadam, R. (2009). Construct validation of a questionnaire on characteristics of successful Iranian EFL teachers (Under Review).

Pajares, M. F. (1992). Teachers' beliefs and educational research: Cleaning up a messy construct. Review of Educational Research 62(3): 307-332.

Park, G.P. and Lee, H.W. (2006). The characteristics of effective English teachers as perceived by high school teachers and students in Korea. Asia Pacific Education Review 7(2): 236-248.

Preus, B. (2007). Educational trends in China and the United States: Proverbial pendulum or potential for bias. Phi Delta Kappan 89: 115-118.

Ross, J.A. (1994). Beliefs that make a difference: The origins and impacts of teacher efficacy. Paper presented at the annual meeting of the Canadian Association for Curriculum Studies.

Siebert, M.C. (2006). An examination of students' perceptions of goal orientation in the classroom and teachers' beliefs about intelligence and teacher efficacy.
Sci. Technol. Arts Res. J., April-June 2014, 3(2): 221-228

PhD Dissertation, Kansas State University, UMI Number: 3244639.

Skaalvik, E.M. and Skaalvik, S. (2007). Dimensions of teacher self-efficacy and relations with strain factors, perceived collective teacher efficacy, and teacher burnout. Journal of Educational Psychology 99: 611625.

Stein, M.K. and M.C. Wang, 1988. Teacher Development and School Improvement: The Process of Teacher Change. Teaching and Teacher Education 4: 171-187.

Tschannen-Moran, M. and Barr, M. (2004). Fostering Student Leaning: The relationship of Collective Teacher Efficacy and Student Achievement. Leadership and Policy in Schools 3(3): 189-209.

Tschannen-Moran, M., and Woolfolk Hoy, A. (2001). Teacher efficacy: Capturing an elusive construct. Teaching and Teacher Education 17: 783-805.

Tschannen-Moran, M., Woolfolk Hoy, A. and Hoy, W.K. (1998). Teacher efficacy: Its meaning and measure. Review of Educational Research 68: 202-248.

Woolfolk Hoy, A.W. and Burke Spero, R. (2000). Changes in teacher efficacy during the early years of teaching: an exploratory study. Retrieved April 2014, from http://des.emory.edu/mfp/efftalk.html.

Witcher, A., Onwuegbuzie, A. and Minor, L. (2001). Characteristics of effective teachers: Perceptions of preservice teachers. Research in the Schools 8: 45-57.

Wolters, C.A. and Daugherty, S.G. (2007). Goal structures and teachers' sense of efficacy: Their relation and association to teaching experience and academic level. Journal of Educational Psychology 99: 181-193.

Yeom, M. and Ginsburg, M. (2007). Professionalism and the reform of teachers and teacher education in the Republic of Korea and the United States of America. Asia Pacific Education Review 8: 298-310.

Zembylas, M., and Papanastasiou, E. (2004). Job satisfaction among school teachers in Cyprus. Journal of Educational Administration 42: 357-374. 